\title{
Paweł Falenta
}

Uniwersytet Wrocławski

p.falenta@gmail.com

\section{Etyka urzędnika - założenia a rzeczywistość. Próba oceny na tle wybranych regulacji etycznych}

\author{
The official's ethics - assumptions and reality. An attempt to \\ evaluate against the background of selected ethical regulations
}

\section{STRESZCZENIE}

Artykuł będzie dotyczył zagadnienia etycznego postępowania urzędników z uwzględnieniem standardów krajowych jak i międzynarodowych w tym zakresie. Zostaną w nim zaprezentowane podstawowe regulacje dotyczące etyki pracowników sektora publicznego, ze szczególnym zwróceniem uwagi na możliwość nieprawidłowości w tym zakresie. Dokonana zostanie analiza porównawcza uregulowań zawartych w Europejskim Kodeksie Dobrej Administracji oraz Kodeksie etyki służby cywilnej, która pokaże w jakiś sposób rozumiana jest etyka z różnych punktów widzenia, co jest przedmiotem zainteresowania, a co zostało pominięte w tych dwóch regulacjach. Ukazane zostaną także poszczególne studia przypadków wynikające $\mathrm{z}$ doświadczeń autora oraz omówione zagadnienie odpowiedzialności dyscyplinarnej. Artykuł będzie próbą oceny i odniesienia regulacji teoretycznych do praktyki, obserwowanej zarówno przez samego autora, jak i z wynikającej z badań przeprowadzanych w tym zakresie.

Słowa kluczowe: etyka, sektor publiczny, urzędnik, odpowiedzialność, kodeks etyki

\section{WSTĘP}

Punktem wyjścia do rozważań jest określenie pojęcia etyka, aby w dalszej kolejności przejść do zagadnienia związanymi ze standardami etycznymi urzędnika ${ }^{1}$. Pojęcie etyka z greckiego „tá êthiká” oznacza 'traktat o obyczajach' ,éthos” obyczaj', 'charakter'. Był to termin użyty w IV w. p.n.e. przez Arystotelesa w tytule dzieła „Etyka nikomachejska” na oznaczenie opisowo-krytycznego studium tego,

$1 \quad$ Ilekroć w niniejszym artykule jest mowa o urzędniku służby cywilnej rozumie się przez to zarówno urzędnika mianowanego jak i pracownika służby cywilnej. 
co dotyczy etosu jako ludzkiego charakteru, obyczaju, tj. utrwalonego sposobu zachowania się w środowisku życia, zamieszkania. W sensie potocznym — etyka to ogół norm moralnych uznawanych w pewnym czasie przez jakąś zbiorowość społeczną jako punkt odniesienia dla oceny i regulacji postępowania w celu integracji grupy wokół pewnych wartości; w sensie filozoficznym - etyka to nauka dotycząca moralności, rozpatrywana odrębnie w aspektach: normatywnym jako nauka moralności (tzw. etyka normatywna lub etyka właściwa) oraz opisowo-wyjaśniającym jako nauka o moralności (tzw. etyka opisowa lub etologia)2. Etykę można także określić jako naukę filozoficzną obejmującą zespół zagadnień moralności w relacji do dobra i zła moralnego; w ujęciu naukowym etyka określa istotę powinności moralnej człowieka oraz jej szczegółowej treści (słuszności moralnej) i ostatecznie wyjaśnia fakt moralnego działania. Wskazuje ponadto na genezę zła moralnego oraz sposoby jego przezwyciężania ${ }^{3}$. Etyka stanowi część normatywną etosu; w jej skład wchodzą: etyka gospodarcza, etyka polityczna i etyka społeczna ${ }^{4}$.

Etyka administracji publicznej to z kolei etyka wypływająca m.in. z ,prawa do dobrej administracji”. Rozumiana jako zastępowanie postawy władczej - usługową, a ostatecznie - partnerską („oświadczenia zamiast zaświadczeń”), w miarę wzrostu świadomości prawnej obywateli5. Sprostanie zadaniu realizacji służby publicznej w sposób sprawny, zgodnie z potrzebami społeczeństwa i oczekiwaną przez niego wysoką jakością pracy, wymaga wdrożenia i przestrzegania w administracji zasad etycznych ${ }^{6}$. Odnoszą etykę do kwestii prawnych można przy tym stwierdzić, że „nieuprawnione jest twierdzenie, że norma etyczna musi być zgodna z normą prawną (...)To raczej prawo powinno mieć legitymację etyczną. Przedmiotem oceny nie może być sama norma etyczna, a jedynie norma prawna, którą norma etyczna dookreśla"7. Kodeks etyczny to natomiast pewien sformalizowany zbiór zasad, dotyczące wykonywania określonego zawodu czy funkcji społecznej. Etyka konkretnego zawodu powinna być rozumiana w sposób bardziej kompleksowy niż tylko zapisy odnośnego jej kodeksu. Może ona: być wywiedziona z etyki ogólnej, z uwzględnieniem konkretnej teorii etycznej, czyli skonstruowana odgórnie, lub też wynikać przede wszystkim ze specyfiki zawodu, a nie odgórnych założeń etycznych, tym samym zaś tworzona oddolnie ${ }^{8}$.

\footnotetext{
2 http://encyklopedia.pwn.pl/haslo/etyka;3898956.html, (data dostępu 22.04.2018 r.).

3 A. Zadroga, Wspótczesne ujęcia etyki biznesu w Polsce. Próba oceny z perspektywy teologii moralnej, Wydawnictwo, Lublin 2009, s. 24.

4 Ibidem.

5 https://www.kul.pl/files/602/etyka/Etyka-w-administracji.ppt, (data dostępu 22.04.2018 r.).

6 T. Kowalski, Kodeks etyczny a ksztaltowanie zasad etycznych w administracji, PWSZ, Sulechów 2005, s. 1.

7 Postanowienie TK z dnia 7 października 1992 r., sygn. akt U 1/92, OTK 1992/Nr 2, poz. 38.

8 M. Nowak, Etyka księgowego i biegłego rewidenta w świetle zjawiska finansokracji - pomiędzy etyka ogólna a szczegółową, „Studia Ekonomiczne. Zeszyty Naukowe UE w Katowicach”, 2017, nr 322.
} 
Niniejszy artykuł ma pokazać wybrane regulacje etyczne obowiązujące w administracji publicznych, z uwzględnieniem regulacji krajowych (kodeksów etycznych) z odniesieniem do regulacji europejskich. W celu pełnego zobrazowania wybranych postanowień etycznych przeprowadzona zostanie analiza porównawcza kodeksu etycznego obowiązującego w służbie cywilnej ${ }^{9}$ w zestawieniu z Europejskim Kodeksem Dobrej Administracji. Analiza pozwoli na określenie różnić i podobieństw obu regulacji, pozwoli też opatrzyć je stosownym komentarzem odautorskim w zakresie występujących problemów praktycznych. Autor odniesie się również do kwestii odpowiedzialności dyscyplinarnej za naruszenie zasad etycznych przez urzędnika. W pracy posłużono się metodą analityczną, metodą analizy unormowań prawnych oraz studiami przypadków (doświadczeń autora).

\section{WYBRANE REGULACJE PRAWNE NA POZIOMIE EUROPEJSKIM I KRAJOWYM}

Na poziomie Unii Europejskiej znajdziemy szereg regulacja związanych bezpośrednio lub pośrednio $\mathrm{z}$ kwestiami etycznego postępowania urzędników administracji publicznej. Zaliczymy do nich m.in. Kartę Praw Podstawowych Unii Europejskiej ${ }^{10}$, Europejski Kodeks Dobrej Administracji ${ }^{11}$, Europejską Kartę Samorządu Terytorialnego ${ }^{12}$, Rekomendację Rady dotyczącą poprawy etycznego postępowania w służbie publicznej, obejmująca zasady zarządzania kwestiami etycznymi w służbie publicznej ${ }^{13}$, Decyzję Komisji z dnia 28 kwietnia 1999 r. ustanawiająca Europejski Urząd ds. Zwalczania Nadużyć Finansowych (OLAF) $(1999 / 352 / W E, \text { EWWiS, Euratom })^{14}$, Decyzję Ramową Rady z dnia 26 czerwca 2001 r. w sprawie prania brudnych pieniędzy oraz identyfikacji, wykrywania, zamrożenia, zajęcia i konfiskaty narzędzi oraz zysków pochodzących z przestępstwa (2001/500/WSiSW) ${ }^{15}$ i wiele innych. Na poziomie krajowym do regulacji związanych z etyką urzędniczą zaliczymy m.in.: ustawę z dnia 21 listopada $2008 \mathrm{r}$.

9 Z uwagi na szerokie ramy tematu, a ograniczenie artykułu, nie jest możliwa pełna analiza naukowa urzędników każdego szczebla administracji publicznej w Polsce.

10 Karta Praw Podstawowych Unii Europejskiej (Dz. U. UE 2012/C 326/02).

11 Decyzja Parlamentu Europejskiego z dnia 6 września 2001 r. w sprawie Kodeksu Dobrej Praktyki Administracyjnej (Dz. U. UE 2011/C 285/03). W oryginale aktu została użyta nazwa „Europejski Kodeks Dobrej Praktyki Administracyjnej”. Dla uzyskania większej komunikatywności w tekście artykułu określenia „Europejski Kodeks Dobrej Administracji” oraz skrótu „KDA”.

12 Europejska Karta Samorządu Terytorialnego przyjęta 15 października 1985 r. (Dz. U. 124 poz. 907 i 908).

13 Rekomendacja Rady z dnia 23 kwietnia 1998 r. (Dz. U. WE C(98)70), (wersja ostateczna).

14 Dz. U. WE z 31.5.1999, L 136/20.

15 Dz. U. WE z 5.7.2001, L 182/1. 
o służbie cywilnej ${ }^{16}$, Kodeks Etyki Służby Cywilnej RP ${ }^{17}$, Uchwałę nr 37 Rady Ministrów z dnia 1 kwietnia 2014 r. w sprawie Rządowego Programu Przeciwdziałania Korupcji na lata $2014-2019^{18}$, kodeksy etyczne poszczególnych zawodów, kodeksy etyczne wewnętrzne jednostek samorządu terytorialnego i inne.

\section{OGÓLNE ZASADY ETYCZNE ADMINISTRACJI PUBLICZNEJ W WYBRANYCH AKTACH PRAWNYCH}

Pierwszą regulacją wartą wymienienia jest art. 41 Karty Praw Podstawowych UE, który zapewnia wszystkim tzw. prawo do dobrej administracji. Precyzuje on, że: ,każdy ma prawo do bezstronnego i rzetelnego załatwienia jego sprawy w rozsądnym terminie przez instytucje, organy i agencje Unii”. W punkcie 2 określa, że prawo to obejmuje: ,prawo każdej osoby do osobistego przedstawienia sprawy, zanim zostanie podjęty indywidualny środek mogący negatywnie wpłynąć na jej sytuację; prawo każdej osoby dostępu do akt jej sprawy, z zastrzeżeniem poszanowania uprawnionych interesów poufności oraz tajemnicy zawodowej i handlowej; obowiązek administracji uzasadniania swoich decyzji”, a w pkt 3 dodaje, że „każda osoba ma prawo domagania się od Wspólnoty naprawienia, zgodnie z zasadami ogólnymi wspólnymi dla praw Państw Członkowskich, szkody wyrządzonej przez jej instytucje lub jej pracowników przy wykonywaniu ich funkcji”. Każda osoba może się przy tym zwrócić pisemnie do instytucji Unii w jednym z języków traktatowych i musi otrzymać odpowiedź w tym samym języku. Zasady te stanowią jednocześnie podstawy do obowiązywania zasad postępowania administracyjnego określonych w $\mathrm{KDA}^{19}$. Sam KDA jest bardzo treściwy, a zarazem zwięzły; składa się z zaledwie 27 artykułów ${ }^{20}$. Zawiera on wskazówki o charakterze ogólnym, co oczywiście nie wyłącza także stosowania szczegółowych postanowień zawartych w polskich postępowaniach administracyjnych ${ }^{21}$. Analizując poszczególne przepisy ww. kodeksu będziemy można stwierdzić, że postanowienia uzupełniają przepisy polskiego prawa i praktykę jego stosowania, inne zaś zawierają wyłącznie identyczne lub podobne regulacje. Należy także podkreślić, że ww. kodeks nie ma mocy bezwzględnie obowiązującej, nawet po wstąpieniu Polski w struktury Unii Europejskiej.

16 Dz.U. 2008 nr 227 poz. 1505 z późn. zm.

17 Zarządzenie Nr 70 Prezesa Rady Ministrów z dnia 6 października 2011 r. w sprawie wytycznych w zakresie przestrzegania zasad służby cywilnej oraz w sprawie zasad etyki korpusu służby cywilnej (M.P. Nr 93, poz. 953.), dalej KESC.

18 M.P. Poz. 299.

19 B. Adamiak, J. Borkowski, Postepowanie administracyjne i sadowoadministracyjne, Warszawa 2014, s. 33.

20 J. Świątkiewicz, Europejski Kodeks Dobrej Administracji, Warszawa 2002, s. 8.

${ }^{21}$ Ibidem. 
Jego postanowienia mają jedynie charakter zaleceń czy wytycznych w sprawach załatwianych przez organy Unii Europejskiej, analogicznie, organy krajowe. Zalecenia te mogą odgrywają jednak bardzo pozytywną rolę w usprawnianiu działalności administracji publicznej oraz pogłębianiu praworządności i zaufania w stosunku do administracji publicznej. Europejska Karta Samorządu Terytorialnego zakłada natomiast $\mathrm{w}$ art. 6 ust. 2, że: ,status pracowników samorządowych powinien umożliwiać zatrudnianie pracowników wysoko wykwalifikowanych, w oparciu o kryterium umiejętności i kompetencji; w tym celu należy przewidzieć odpowiednie zasady szkolenia, wynagradzania oraz możliwości awansu zawodowego". Na gruncie krajowym istotny jest z kolei art. 76 Ustawy z dnia 21 listopada 2008 r. o służbie cywilnej, zgodnie z którym członek korpusu służby cywilnej jest obowiązany w szczególności: „1) przestrzegać Konstytucji Rzeczypospolitej Polskiej i innych przepisów prawa; 2) chronić interesy państwa oraz prawa człowieka i obywatela; 3) racjonalnie gospodarować środkami publicznymi; 4) rzetelnie i bezstronnie, sprawnie i terminowo wykonywać powierzone zadania; 5) dochowywać tajemnicy ustawowo chronionej; 6) rozwijać wiedzę zawodową; 7) godnie zachowywać się w służbie oraz poza nią".

\section{ANALIZA PORÓWNAWCZA WYBRANYCH STANDARDÓW ETYCZNYCH URZĘDNIKA SŁUŻBY CYWILNEJ}

Istotne wydaje się, na wstępie sformułować, podążając za P. Fenrychem, iż urzędnik w swoim działaniu powinien być: bezstronny- wszelkie decyzje powinien podejmować w imię dobra publicznego, pomijając własne korzyści, bądź korzyści osób lub organizacji sobie bliskich; obiektywny- wszelkie decyzje powinien podejmować kierując się wyłączne kryteriami merytorycznymi; przejrzysty- wszystkie decyzje powinien podejmować w sposób jawny i uzasadniony, jak tylko jest to możliwe, a każda decyzja powinna mieć jawne uzasadnienie, a ograniczenie tej zasady musi stanowić wyjątek motywowany doborem publicznym; rzetelny - realizujący zadania z należytą starannością i sumiennością; odpowiedzialny- świadomy, że działa w interesie społecznym i odpowiada przed społeczeństwem za swoje decyzje ${ }^{22}$. Takie kompleksowe ujęcie zasad buduje rzeczywisty etos urzędnika i zasady, którymi powinien się kierować.

Analizując regulacje zawarte w KESC rozpocząć należy od ogólnej zasady godnego zachowania. Odnosi się ona do wykonywania pracy z zachowaniem kultury i zasad współżycia społecznego, zachowania życzliwości jak również właściwej

22 P. Fenrych, Etyka w działaniu urzędnika publicznego, [w:] C. Trutkowski, P. Koryś, Przeciwdziałanie korupcji w praktyce. Polityka antykorupcyjna w polskiej administracji publicznej, Warszawa 2013, s. 23. 
postawy poza pracą. Analogiczną zasadą ujętą w KDA jest zasada uprzejmości. Regulacje w niej zawarte są zasadniczo tożsame, jednak z jednym wyjątkiem ujętym w regule, że „w przypadku popełnienia błędu naruszającego prawa lub interes jednostki urzędnik przeprasza za to i stara się skorygować negatywne skutki popełnionego przez siebie błędu w jak najwłaściwszy sposób, informując o ewentualnych możliwościach odwołania się zgodnie z art. 19 Kodeksu". Regulacja ta niebezpośredniego przełożenia na krajowe przepisy. Może być jednak realizowana m.in. poprzez sprostowania rzecznika prasowego, system realizacji skarg i wniosków czy realizację wyroku sądowego nakazującego przeprosiny. Pojawia się tutaj zarazem kwestia, na ile urzędnik, chcąc ocenić pracę swojego urzędu, mógłby w ramach potencjalnych przeprosin ocenić negatywnie swojego pracodawcę. Warto tu przywołać jedno z orzeczeń, zgodnie z którym ,pracownik służby cywilnej może wyrażać opinie o swoim zakładzie pracy czy przełożonym, winien to jednak czynić w sposób stosowny. Niedopuszczalne jest wyrażanie dezaprobaty dla kierownika zakładu pracy w sposób agresywny, w obraźliwych słowach. Takie zachowanie stanowi naruszenie obowiązków członka korpusu służby cywilnej i winno skutkować, co najmniej, zastosowaniem jednej z kar dyscyplinarnych przewidzianych w ustawie z dnia 21 listopada 2008 r. o służbie cywilnej (Dz.U. Nr 227, poz. 1505 ze zm.)"233.

Kolejna z zasad to zasada służby publicznej podnosząca służebną rolę urzędników, służbę państwu, kształtowanie pozytywnego wizerunku służby cywilnej, wyższość dobra wspólnego obywateli, nieuchylanie się od odpowiedzialności. W KDA zasadę te można powiązać z zasadą „oczekiwania prawnie uzasadnione oraz konsekwentne działanie i doradztwo". Dość problematyczne mogłoby być realizowanie postulatu zawartego $\mathrm{w}$ tejże zasadzie dotyczącego uwzględniania słusznych oczekiwań jednostki oraz bezwzględnego służenia jednostce poradą. W realiach i strukturach podległości urzędnik - klient, porady ograniczane są na ogół do bardzo ogólnych informacji, natomiast spełnienie oczekiwań często sprowadza się do realizacji pod kątem zgodności z prawem, z mniejszą korelacją z rozsąanym załatwieniem sprawy w celu jak najlepszej realizacji sprawy. W KDA nie ma natomiast zupełnie odzwierciedlenia zasada lojalności wynikająca z KESC. Oznacza ona lojalność wobec państwa, programów rządowych, wobec urzędu i przełożonych, powściągliwości w wypowiadaniu się publicznie nt. funkcjonowania urzędu i spraw w nim realizowanych (także w kwestii opinii o swoim zakładzie pracy, o czym wcześniej).

Kolejne dwie zasady ze sobą powiązane to zasada bezstronności i neutralności politycznej z KESC mające odniesienie w KDA w zasadach bezstronności i niezależności, zakazu nadużywania uprawnień, obiektywności, uczciwości. Nakazują one urzędnikom unikanie konfliktów interesów, przestrzeganie zasady równouprawnienia w traktowaniu klientów, unikanie zażyłości z osobami publicznymi,

23 Wyrok SA w Rzeszowie z dnia 8 listopada 2012 r., sygn. akt. APo 7/12, Legalis 715047. 
niemanifestowanie poglądów politycznych, dystansowanie się od wpływów i nacisków, dbałość o przejrzystość relacji z osobami publicznymi.

Przedostatnią zasadą wartą wymienienia jest zasada rzetelności mająca odpowiednik w KDA w zasadzie praworządności. Sprowadza się ona do sumiennego i rozważnego wykonywania zadań, legalizmu, stosowania procedur, dobrej woli w realizacji obowiązków. Ostatnia z zasad ujęta z kolei w KDA, której brak w krajowej regulacji to zasada niedyskryminowania. Dotyczy ona trzech istotnych postulatów: „1. przy rozpatrywaniu wniosków jednostek i przy podejmowaniu decyzji urzędnik zapewni przestrzeganie zasady równego traktowania, a pojedyncze osoby znajdujące się w takiej samej sytuacji będą traktowane w porównywalny sposób; 2 . W przypadku różnic w traktowaniu urzędnik zapewni, aby to nierówne traktowanie było usprawiedliwione obiektywnymi, istotnymi właściwościami danej sprawy; 3 . Urzędnik powstrzyma się w szczególności od wszelkiego nieusprawiedliwionego nierównego traktowania jednostek ze względu na ich narodowość, płeć, rasę, kolor skóry, pochodzenie etniczne lub społeczne, cechy genetyczne, język, religię lub wyznanie, przekonania polityczne lub inne; przynależność do mniejszości narodowej, posiadaną własność, urodzenie, inwalidztwo, wiek lub orientację seksualną."

\section{ZASADY KESC W ŚWIETLE ROZWAŻAŃ I PROBLEMÓW PRAKTYCZNYCH}

W odniesieniu do wyżej wymienionych zasad sensu stricte dokonano analizy wybranych zasad pod kątem ich stosowania w praktyce, problemów z ich realizacją, zalet i wad poszczególnych zasad, spojrzenia na zasady z punktu widzenia zarówno urzędnika, jak i potencjalnego klienta urzędu. Pierwszą omawianą zasadą jest zasada bezstronności, w której skupiono się na omówieniu jej części szczegółowej, zgodnie z którą członek korpusu służby cywilnej ,(...) rezygnuje z dodatkowego zatrudnienia lub zajęcia zarobkowego, jeżeli dalsze wykonywanie dodatkowego zatrudnienia lub zajęcia zarobkowego może mieć negatywny wpływ na sprawy prowadzone w ramach obowiązków służbowych; nie prowadzi szkoleń, jeżeli mogłoby to negatywnie wpłynąć na bezstronność prowadzonych spraw". Nietrudno sobie wyobrazić problemy praktyczne związane z realizacją tych założeń. Po pierwsze, należy sobie zadać pytanie, czy praca w służbie cywilnej powinna wprowadzać aż takie ograniczenia. Założenia wydzielenia tego typu służby w administracji publicznej związane było z koniecznością uregulowania tej sfery, zapewnienia jej możliwej profesjonalizacji i standardów działania. Należy jednak osadzić funkcjonowanie takiej służby w kontekście całego systemu zarządzania, edukacji, możliwości zarobkowania i poziomu wynagrodzeń. Wynagrodzenia w służbie cywilnej nie należą do najwyższych (średnio 5.266,00 zł brutto w 2016 r. przy 118,8 tys. 
urzędników, w tym na stanowiskach kierowniczych ${ }^{24}$ ), a kwota bazowa będąca podstawą ustalania wynagrodzeń nie zmieniła się do 2008 r. To skłania urzędników do podejmowania dodatkowej działalności mającej poprawić ich status materialny, na ogół tej najmniej kolidującej z pracą w urzędzie: prowadzenia zajęć w szkołach, prowadzenia szkoleń, realizacja małych zleceń etc. Takie dodatkowe zatrudnienie, nie tylko powoduje wzrost poziomu materialnego, ale także wzrostu kompetencji tych urzędników. To powoduje, postawienie kolejnego pytania: czy dzielenie się wiedzą (zdobytą często za własne pieniądze) powinno być ograniczane niejasnymi kryteriami bezstronności? Rodzi się także obawa czy takie ograniczenie nie skłaniają do podejmowania ukrytych działań (może nieetycznych?). Urzędnicy mogą bowiem, co jest stwierdzoną praktyką, nie informować swoich pracodawców o podejmowaniu dodatkowych działań zarobkowych z obawy przed ujawnieniem naruszenia kodeksu etyki. Zaznaczyć przy tym należy, że choć ryzyko, że takie działania mogą mieć negatywny wpływ na wykonywania obowiązków istnieje, to jednak są to sytuacje marginalne i mocno ograniczone.

Druga wątpliwość pojawia się na tle zasady odpowiedzialności i jej uszczegółowienia w postaci zapisu, że urzędnik ,przy wykonywaniu zadań kieruje się interesem publicznym i efektywnością oraz zgodnością podejmowanych działań z przepisami; jeżeli zachodzi rozbieżność między przepisami prawa a interesem publicznym, sygnalizuje to przełożonym; $w$ razie postawienia zarzutu naruszenia obowiązków członka korpusu służby cywilnej nie podejmuje działań zmierzających do zakłócenia sprawnego przebiegu postępowania mającego na celu ustalenie osoby za to odpowiedzialnej; jeżeli jest przekonany, że polecenie służbowe przełożonego narusza zasady służby cywilnej, informuje go lub jego przełożonych na piśmie." Sytuacja istnienia rozbieżności między przepisami prawa a interesem publicznym zdarza się bardzo często. W swoich rozstrzygnięciach wielu urzędników stara się zwracać uwagę na interes publiczny, dobro klienta, kierować się doświadczeniem życiowym, co nie jest zadaniem łatwym do spełnienia, gdyż dominujący legalizm często nie pozwala na jakiekolwiek działania. Czy zatem zgłaszanie tego przełożonym może mieć jakiś skutek? Tak, głównie dla zgłaszającego i niekoniecznie pozytywny. Przełożeni często nie rozumiejąc materii danej sprawy, odbierają takie działanie jako mało profesjonalne, mogące mieć podłoże korupcyjne, co ostatecznie przekłada się na negatywną ocenę takiego urzędnika. Rodzi to kolejne pytania: czy w przypadku zarzutów dla członka korpusu służby cywilnej ma być on bierny, czy może od razu powinien wziąć na siebie winę, aby przyspieszyć procedurę. Nie mniejszy problem występuje, kiedy pracownicy odmawiają zasadnie wykonania niektórych poleceń służbowych naruszających zasady służby cywilnej. Takie przypadki są jednak rzadkością, gdyż obawa konsekwencji jest tutaj wystarczającą

${ }^{24} \mathrm{http} / /$ ksiegowosc-budzetowa.infor.pl/kadry-i-place/wynagrodzenia/762039,Pracownicy-administracji-rzadowej-bez-podwyzek-w-2018-r.html, (data dostępu: 16.05.2018 r.). 
blokadą. Są to niewątpliwie dylematy, faktyczne i prawne, z którymi na co dzień musi zmierzyć się urzędnik. To jakie ostatecznie podejmie rozstrzygnięcie determinować będzie na ogół jego dalszą karierę.

Trzecia wątpliwość związana jest z uszczegółowieniem zasady profesjonalizmu w postaci zapisu, że urzędnik: „korzystając z zagwarantowanych praw pracowniczych (...) ma na względzie wynikające z przepisów ograniczenia poufności informacji dotyczącej również jego życia osobistego” oraz że „korzystając z określonej w przepisach szczególnej ochrony stosunku pracy urzędnika służby cywilnej, ma na względzie cel tej szczególnej ochrony, którym jest: pozyskiwanie i zatrzymywanie w służbie cywilnej osób, które swój profesjonalny rozwój wiążą z pracą w administracji rządowej; ochrona zatrudnienia w służbie cywilnej osób, które wykazały w swojej pracy zdolność do profesjonalnego i etycznego zachowania członka korpusu służby cywilnej, a w szczególności przestrzegały zasady neutralności politycznej i bezstronności służby cywilnej”. Na początku można mieć uzasadnioną wątpliwość czy ingerencja w ograniczenia życia osobistego z racji pracy w służbie cywilnej to nie za daleko posunięte regulacje w prawach człowieka i obywatela nieadekwatne do charakteru wykonywanej pracy a zarazem, czy bycie urzędnikiem to świadoma rezygnacja/ograniczenie prywatności w zamian za stabilność zatrudnienia, prestiż etc. Takie ograniczenia powinny być odpowiednie do charakteru pracy i mogą mieć zastosowanie do pracy np. w służbach specjalnych, jednak rodzi się wątpliwość czy standardowa praca urzędnicza, choćby systemowo ważna i doniosła, musi wpływać aż na ograniczenia życia osobistego, poza ogólnymi normami dotyczącymi godnego zachowania. Warto też podkreślić, że np. orzeczenia dyscyplinarne dotyczące członków korpusu służby cywilnej dotyczące przewinień związanych z wykonywaniem ich funkcji są informacjami publicznymi nie podlegającymi ograniczeniom co do dostępu ${ }^{25}$, co powoduje zupełna utratę prywatności, a często dodatkowo ostracyzm społeczny. Druga kwestia odnosi się do takiej konstrukcji stosunku pracy urzędnika (czy też pracownika) służby cywilnej, która zmierza do jego ochrony w aspekcie zatrzymywania osób o najwyższych kwalifikacjach. $Z$ doświadczeń autora wynika, że choć są do tego odpowiednie narzędzia i rozwiązania prawne, to rzadko się z nich adekwatnie i efektywnie korzysta. Często brakuje obiektywizmu w ocenach pracowników, brak jest woli przełożonych, potencjalny awans pracownika traktuje się jako zagrożenie dla własnej pozycji. Takie postawy z pewnością nie sprzyjają zatrzymywaniu w urzędach osób o najwyższych kwalifikacjach (fluktuacja zatrudnienia w 2016 r. wyniosła 7\%, względem 2010 r. zatrudnienie spadło łącznie o 4141 etatów , najwięcej wśród specjalistów i wyższych stanowisk ${ }^{26}$ ). Na koniec można postawić następujące tezy: czy faktycznie jest ochrona osób wykazujących

25 Wyrok WSA w Szczecinie z dnia 26 września 2012 r., sygn. akt II SA/Sz 536/12, Legalis 558267.

$26 \mathrm{https} / / / \mathrm{dsc} . \mathrm{kprm} . g o v \cdot p 1 / \mathrm{sites} / \mathrm{default} /$ files/sprawozdanie_2017-03-30_-_do_druku_z_podpisem_0.pdf. (data dostępu: 16.05.2018 r.). 
się profesjonalnym i etycznym zachowaniem? Czy może raczej ochrony dotyczy osób niekoniecznie neutralnych politycznie? Czy neutralność polityczna w służbie cywilnej nie jest tylko utopijnym standardem niemożliwym do realizacji?

\section{ODPOWIEDZIALNOŚĆ DYSCYPLINARNA URZĘDNIKA W SŁUŻBIE CYWILNEJ}

Przestrzeganie KESC związane jest także z kwestią ewentualnej odpowiedzialności dyscyplinarnej urzędnika. Zgodnie z art. 113 ust. 1 ustawy o służbie cywilnej „Członek korpusu służby cywilnej odpowiada dyscyplinarnie za naruszenie obowiązków członka korpusu służby cywilnej”. Ten oczywisty przepis jest istotny pod tym względem, iż uniemożliwia zastosowanie wobec członka korpusu służby cywilnej przepisów odpowiedzialności porządkowej pracownika z rozdziału VI Kodeksu pra$\mathrm{cy}^{27}$. Jednak dyrektor generalny danego urzędu ma prawo rozwiązać umowę o pracę za wypowiedzeniem (art. 32 k.p. w zw. z art. 9 ust. 1 ustawy o służbie cywilnej) z pracownikiem służby cywilnej (inaczej w przypadku urzędnika mianowanego), i to bez konieczności wszczynania procedury dyscyplinarnej ${ }^{28}$. Przebieg postępowania uregulowany jest $\mathrm{w}$ art. 115 do 131 tejże ustawy. Ogólnie można powiedzieć, że odpowiedzialność dyscyplinarna to „odpowiedzialność członków korpusu służby cywilnej ponoszona przed władzą przełożoną lub specjalnie powołanymi organami egzekwowania tej odpowiedzialności z tytułu przekroczeń służbowych i naruszenia obowiązków w trakcie urzędowania jak i poza nim ${ }^{29}$. Art. 113 ustawy o służbie cywilnej (ani żaden inny spośród regulacji rozdziału 9) nie deklaruje wprost (co występowało w ustawie z 1996 r.) jednej z podstawowych zasad postępowania dyscyplinarnego, tj. zasady niezależności tego postępowania, oznaczającej możliwość wszczęcia postępowania dyscyplinarnego niezależnie od toczącego się innego postępowania prawnego (np. karnego, karnego skarbowego) oraz wymierzenia kary dyscyplinarnej za dany czyn niezależnie od innych wymierzonych kar - zasada ta jest głęboko osadzona w założeniach, celach oraz funkcjach odpowiedzialności dyscyplinarnej ${ }^{30}$. W założeniu bowiem odpowiedzialność dyscyplinarna służy nie tyle karaniu osób za naganne czyny, ile doskonaleniu całego korpusu służby cywilnej przez uruchamianie procedury sprawiedliwego i konsekwentnego reagowania na wadliwe zachowania członków tego korpusu. Dlatego też wydaje się, że pomimo braku wyrażenia expressis

27 Ustawa z dnia 26 czerwca 1974 r. Kodeks pracy (Dz. U. nr 24, poz. 141 z późn. zm.).

28 A. Jezierska-Markocka, M. Markocki, Stużba cywilna. Stosunek pracy. Zarządzania zasobami ludzkimi., Legalis 2016; vide: wyrok SN z 19 kwietnia 2012 r., sygn., akt II PK 203/11, OSNAPiUS 2013, Nr 7-8, poz. 75.

29 J. Jagielski, K. Rączka, Ustawa o stużbie cywilnej. Komentarz., Warszawa - LEX 2010.

30 Ibidem. 
verbis przez obecne przepisy zasady niezależności postępowania dyscyplinarnego, taka zasada znajduje zastosowanie również w odniesieniu do obowiązującej dzisiaj odpowiedzialności dyscyplinarnej członków korpusu służby cywilnej ${ }^{31}$. W doktrynie spotkać można również pogląd, zgodnie z którym odpowiedzialność dyscyplinarna ze względu na represyjny charakter sankcji jest częścią odpowiedzialności karnejej2, lub też jest rodzajem odpowiedzialności zbliżonym do odpowiedzialności karnej ${ }^{33}$. Przypisanie odpowiedzialności i wszczęcie postępowania dyscyplinarnego wobec urzędnika, w tym za naruszenie zasad etyki, wymaga wszechstronnej analizy materiału dowodowego i zbadania wszystkich aspektów sprawy. Podkreślono to m.in. w jednym $z$ orzeczen ${ }^{34}$, w którym stwierdzono, że „przypisanie odpowiedzialności dyscyplinarnej o charakterze deliktowym nie może opierać się na uprawdopodobnieniu, ale musi wynikać z wykazanych w sposób niezbity i nie budzący jakichkolwiek wątpliwości faktów, które oczywiście dowodzą o naruszeniu obowiązków członka korpusu służby cywilnej. Wymaga to zawsze dowodów nie budzących wątpliwości, spójnych i precyzyjnych, a dokonując ich oceny nie można abstrahować od całokształtu okoliczności, w tym sposobu organizacji pracy, relacji pomiędzy pracownikami, występujących w zakładzie pracy zależności, w tym osobistych sympatii i antypatii, a także pewnych cech osobowościowych uczestników konfliktu i wynikających z tego emocji”. Na koniec należy dodać, że odpowiedzialność dyscyplinarna nie jest jedynym rodzajem odpowiedzialności, na którą jest narażony członek korpusu służby cywilnej, a obok niej istnieje odpowiedzialność porządkowa, karna, materialna (odpowiedzialność pracownika za szkodę wyrządzoną pracodawcy oraz za powierzone mienie) oraz odpowiedzialność za naruszenie dyscypliny finansów publicznych; zasady i warunki odpowiedzialności regulują odpowiednie przepisy ustawowe" ${ }^{{ }^{35}}$.

\section{PODSUMOWANIE}

Kwestie standardów etycznych w pracy urzędnika powinny być podstawowymi normami, których przestrzeganie z zasady nie powinno budzić wątpliwości; niezależnie od wagi rozpatrywanych spraw. Trzeba przy tym także pamiętać, że przynajmniej w pewnym zakresie rozbudowana sfera obowiązków jest rekompensowana przez szczególne uprawnienia członków korpusu, w tym zwłaszcza szcze-

\section{Ibidem.}

32 Za J. Makarewicz, Prawo karne. Wykład porównawczy z uwzględnieniem prawa obowiązującego w Rzeczypospolitej Polskiej, Lwów-Warszawa 1924, s. 3-4.

33 Za A. Bojańczyk, Z problematyki relacji między odpowiedzialnością dyscyplinarną i karną, PiP 2004, z. 9.

34 Wyrok SA w Szczecinie z dnia 11 grudnia 2012 r., sygn. akt III APo 5/12, Legalis 742937.

35 W. Drobny, M. Mazuryk, P. Zuzankiewicz, Ustawa o stużbie cywilnej. Komentarz, Warszawa - LEX 2012. 
gólne uprawnienia urzędników służby cywilnej ${ }^{36}$. W aspekcie kwestii poruszanych w przedmiotowym artykule można sformułować kilka istotnych wniosków. Po pierwsze, ustanawianie kolejnych kodeksów etycznych dla urzędników nie zawsze powoduje, że faktycznie następuje wzrost pozytywnych postaw etycznych. Po drugie, system administracji publicznej nie jest na tyle sprawny, aby wyeliminować wszelkie działania nieetyczne, zwłaszcza korupcyjne. Po trzecie, ustanawiane regulacji etycznych może czasami być związane z działaniami pozornymi, aby stworzyć wrażenie prawidłowego funkcjonowania środowisk działających w pełni etycznie. Analizując postawione wnioski, można za Mario Bunge, argentyńskim filozofem, stwierdzić, że „wskazywana jako znamię naszych czasów potrzeba powoływania coraz to nowych działów etyki zawodowej, jak gdyby w sugestii, że pewne zawody czy funkcje społeczne mają tak wyjątkowy charakter, że obowiązują w nich inne wartości i normy, niż w etyce ogólnej, powszechnej, skierowanej do wszystkich, jest dowodem upadku etyki w ogóle, niskiego poziomu moralności społeczeństwa "37. Nowe regulacje nie rozwiążą więc istniejących problemów, choć dla niektórych mogą stanowić pewny punkt odniesienia. Kwestia sprawności systemu administracji publicznej mogącego wyeliminować działania nieetyczne wymaga niewątpliwie usprawnień. Pozorna, często niekonkurencyjna rekrutacja, niskie wynagrodzenia, brak efektywnych systemów motywacyjnych, brak skutecznych mechanizmów antykorupcyjnych, potęguje słabość tego systemu, zamiast go wzmacniać. Wspomniane regulacje etyczne niejednokrotnie stwarzają tak naprawdę pozory działań, które mają za zadanie stworzyć obraz systemu, w którym poziom etyki uznać można za wystarczający. Można także zadać sobie pytanie, czy nasze regulacje są do końca adekwatne i zgodne $\mathrm{z}$ tymi na poziomie europejskim, wiele założeń jest co do zasady nierealnych, a fakt ich nieprzestrzegania widoczny jest w bardzo wielu przypadkach. Oczywiście w ślad za tym idzie prezentowanie postaw, zwłaszcza kierownictwa wyższego szczebla, które będą swoistym drogowskazem do postępowania na każdym szczeblu administracji. Niniejszy artykuł, można zakończyć myślą Monteskiusza, która powinna przyświecać każdej pracy urzędniczej - ,jeśli reguł moralności nie nosisz w sercu, nie znajdziesz ich w książkach".

\section{BIBLIOGRAFIA}

Adamiak B., Borkowski J., Postępowanie administracyjne i sqdowoadministracyjne, Warszawa 2014. Baran K.W., Komentarz do ustawy o stużbie cywilnej, [w:] Baran K.W., Prawo urzędnicze. Komentarz., Warszawa - LEX 2014.

36 K.W. Baran, Komentarz do ustawy o stużbie cywilnej, [w:] K.W. Baran, Prawo urzędnicze. Komentarz., Warszawa - LEX 2014.

37 M. Bunge, Treatise on Basic Philosophy, Ethics, Montreal 1989, s. 30 i n. 
Bojańczyk A., Z problematyki relacji między odpowiedzialnościa dyscyplinarna i karna, PiP 2004, z. 9. Bunge M., Treatise on Basic Philosophy, Ethics, Montreal 1989.

Decyzja Komisji z dnia 28 kwietnia 1999 r. ustanawiająca Europejski Urząd ds. Zwalczania Nadużyć Finansowych (OLAF) (1999/352/WE, EWWiS, Euratom), Dz. U. WE z 31.5.1999, L 136/20.

Decyzja Parlamentu Europejskiego z dnia 6 września 2001 r. w sprawie Kodeksu Dobrej Praktyki Administracyjnej, Dz. U. UE. c.2011/285/3.

Decyzja Ramowa Rady z dnia 26 czerwca 2001 r. w sprawie prania brudnych pieniędzy oraz identyfikacji, wykrywania, zamrożenia, zajęcia i konfiskaty narzędzi oraz zysków pochodzących z przestępstwa (2001/500/WSiSW), Dz. U. WE z 5.7.2001, L 182/1.

Drobny W., Mazuryk M., Zuzankiewicz P., Ustawa o stużbie cywilnej. Komentarz, Warszawa - LEX 2012.

Europejska Karta Samorządu Terytorialnego przyjęta 15 października 1985 r., Dz. U. 124 poz. 907 i 908.

Fenrych P., Etyka w działaniu urzędnika publicznego, Warszawa 2013.

http://encyklopedia.pwn.pl/haslo/etyka;3898956.html, (data dostępu: 22.04.2018 r.)

http://ksiegowosc-budzetowa.infor.pl/kadry-i-place/wynagrodzenia/762039,Pracownicy-administracji-rzadowej-bez-podwyzek-w-2018-r.html, (data dostępu: 16.05.2018 r.)

https://dsc.kprm.gov.pl/sites/default/files/sprawozdanie_2017-03-30_-_do_druku_z_podpisem_0. pdf. (data dostępu: 16.05.2018 r.).

https://www.kul.pl/files/602/etyka/Etyka-w-administracji.ppt (data dostępu: 22.04.2018 r.)

Jagielski J., Rączka K., Ustawa o stużbie cywilnej. Komentarz., Warszawa - LEX 2010.

Jezierska - Markocka A., Markocki M., Stużba cywilna. Stosunek pracy. Zarzadzania zasobami ludzkimi., Legalis 2016.

Karta Praw Podstawowych Unii Europejskiej, Dz. U. UE 2012/C 326/02.

Kowalski T., Kodeks etyczny a ksztattowanie zasad etycznych w administracji, Sulechów 2005.

Makarewicz J., Prawo karne. Wykład porównawczy z uwzględnieniem prawa obowiąujacego w Rzeczypospolitej Polskiej, Lwów-Warszawa 1924.

Nowak M., Etyka księgowego i biegłego rewidenta w świetle zjawiska finansokracji - pomiędzy etyka ogólnq a szczegółowa, Studia Ekonomiczne. Zeszyty Naukowe UE w Katowicach, nr 322/2017.

Postanowienie TK z dnia 7 października 1992 r., sygn. akt U 1/92, OTK 1992/Nr 2, poz. 38.

Rekomendacja Rady dotycząca poprawy etycznego postępowania w służbie publicznej, obejmująca zasady zarządzania kwestiami etycznymi w służbie publicznej przyjęta 23 kwietnia 1998 r., C(98)70/ (wersja ostateczna).

Świątkiewicz J., Europejski Kodeks Dobrej Administracji, Warszawa 2007.

Uchwała nr 37 Rady Ministrów z dnia 1 kwietnia 2014 r. w sprawie Rządowego Programu Przeciwdziałania Korupcji na lata 2014 - 2019, M.P. Poz. 299.

Ustawa z dnia 21 listopada 2008 r. o służbie cywilnej, Dz.U. 2008 nr 227 poz. 1505 z późn. zm.

Ustawa z dnia 26 czerwca 1974 r. Kodeks pracy, Dz. U. nr 24, poz. 141 z późn. zm.

Wyrok SA w Rzeszowie z dnia 8 listopada 2012 r., sygn. akt. APo 7/12, Legalis 715047.

Wyrok SA w Szczecinie z dnia 11 grudnia 2012 r., sygn. akt III APo 5/12, Legalis 742937.

Wyrok SN z 19 kwietnia 2012 r., sygn. akt II PK 203/11, OSNAPiUS 2013, Nr 7-8, poz. 75.

Wyrok WSA w Szczecinie z dnia 26 września 2012 r., sygn. akt II SA/Sz 536/12, Legalis 558267.

Zadroga A., Wspótczesne ujęcia etyki biznesu w Polsce. Próba oceny z perspektywy teologii moralnej, Wydawnictwo, Lublin 2009.

Zarządzenie Nr 70 Prezesa Rady Ministrów z dnia 6 października 2011 r. w sprawie wytycznych w zakresie przestrzegania zasad służby cywilnej oraz w sprawie zasad etyki korpusu służby cywilnej, M.P. Nr 93, poz. 953. 
Pobrane z czasopisma Studenckie Zeszyty Naukowe http://szn.umcs.pl

Data: $26 / 04 / 2023$ 12:52:31

\section{SUMMARY}

The article will deal with the issue of ethical behavior of officials, taking into account national and international standards in this regard. The paper will present basic regulations regarding the ethics of public sector employees, with particular attention to the possibility of irregularities in this area. A comparative analysis of the regulations included in the European Code of Good Administrative Behavior and the Code of Civil Officials Ethics will be made, which will show somehow the ethics from different points of view, which is of interest and which has been omitted in these two regulations. Also, individual case studies resulting from the author's experience will be shown as well as the issue of disciplinary responsibility discussed. The article will be an attempt to evaluate and refer theoretical regulations to practice, observed both by the author himself and from the results of research carried out in this field.

Key words: ethics, public sector, clerk, responsibility, ethics code. 